\title{
Submission Response Document
}

National Cancer Institute

\section{Source}

National Cancer Institute. Submission Response Document. NCI Thesaurus. Code

C115736.

Records from an approving committee made in response to a specific submission, that contain an acknowledgement and/or approval of specifications and/or modifications to a clinical trial. 